\title{
A Problematização do Formador de Professores de Química no Estudo da Abordagem Temática: uma Análise Constituinte de um Processo de Comunicação
}

Problematization by a Chemistry Teacher Trainer in the Study of Thematic Approach: a Constituent Analysis of a Communication Process

\author{
Fábio Peres Gonçalves, ${ }^{(D)}$ Renata Aragão da Silveira, ${ }^{(D)}$ Lya Piaia
}

\begin{abstract}
Palavras-chave Resumo O estudo da abordagem temática, sustentada no referencial Ensino de Química; teórico de Paulo Freire, no âmbito da formação de professores tem sido Formação de Professores; Paulo Freire. objeto de investigações em Ensino de Ciências. Notoriamente, parte dessas investigações tem tomado como sujeitos de pesquisa docentes da Educação Básica ou estudantes de licenciatura. O presente trabalho investigou como se caracterizou a problematização promovida por um formador durante o desenvolvimento de uma proposta de abordagem temática fundamentada nas contribuições de Paulo Freire no contexto de um estágio curricular supervisionado na componente curricular Química no Ensino Médio. Um diário virtual coletivo foi elaborado e analisado por duas licenciandas e pelo formador durante o estágio supervisionado. $\mathrm{O}$ exame foi orientado pelos procedimentos da análise textual discursiva que foi tomada como constituinte de um processo de comunicação com base na acepção de Paulo Freire sobre o ato educativo. Como resultados destacam-se aspectos da problematização: o respeito ao conhecimento das licenciandas e a consciência do inacabamento na docência. Depreende-se da análise também que essa problematização, ao mesmo tempo em que se caracterizou por indicativos de colaboração com a prática pedagógica das licenciandas, favoreceu reflexões que se direcionaram ao próprio desenvolvimento profissional do formador, de modo que formador e licenciandas puderam conjuntamente se envolver em processo contínuo de humanização.
\end{abstract}


Keywords Abstract In the context of teacher education, the study of the thematic Chemistry approach, supported by Paulo Freire's theoretical framework, has

Teaching; been extensively investigated. Notably, part of these investigations Teacher Training; has taken teachers in initial training or in-service basic education

Paulo Freire. teachers as research subjects. Considering the need for research to include the role of teacher educators, this paper investigates how the problematization promoted by a teacher educator was conducted during the development of a proposal to use the thematic approach, based on Paulo Freire's contributions in the context of a guided teaching internship for chemistry teachers in a high school. For this purpose, a collective virtual diary elaborated by two undergraduate students and the professor during the internship was analyzed. The examination followed the procedures of textual discourse analysis, which was taken as constitutive of a communication process based on Paulo Freire's understanding of the educative act. Among the results, the following aspects of the problematization stood out: awareness of the unfinishedness of the teaching training and respect for the knowledge of the undergraduate students. It is clear from the analysis that, at the same time that this problematization was characterized by indications of collaboration with the pedagogical practice of the undergraduates, it favored reflections that were directed to the professional development of the trainer, so that the trainer and the undergraduates could jointly get involved in a continuous process of humanization.

\section{Introdução}

Paulo Freire é um autor com destaque nas citações de artigos publicados no Brasil acerca da temática formação de professores de Ciências (Razera et al., 2019). De acordo com Jesus e Razera (2020), a maioria das citações a obras do renomado educador brasileiro se caracteriza como necessária no contexto dos artigos, de modo que se afastam daquelas que são de natureza puramente superficial (desnecessárias ou pontuais). Isto sugere que as ideias de Freire têm impacto qualitativo na pesquisa em Ensino de Ciências sobre formação de professores e não somente quantitativo. Como sinalizaram ainda esses autores, as citações das obras de Paulo Freire na pesquisa nesse campo contrastam com os notórios ataques recentes às suas ideias por meio de um projeto neoliberal de educação defendido no âmbito da política brasileira.

Parte dessa produção nacional que trata da problemática da formação de professores de Ciências fundamentada em contribuições teórico-metodológicas de Paulo Freire se relaciona com o que é denominado de abordagem temática. Neres e Gehlen (2018), em uma investigação relativa à inserção de etapas da investigação temática proposta por Freire (2005) em processos de formação de professores de 
Ciências, concluíram que tal inserção é pouco explorada em publicações disseminadas em periódicos e eventos da área de Ensino de Ciências brasileiros.

Cumpre registrar que a análise da literatura também indica que a abordagem temática fundamentada nas contribuições teóricas de Paulo Freire vem sendo tratada na formação inicial de professores, às vezes, de forma pouco coerente com as ideias do autor (Halmenschlager et al., 2015). Isso pode ser um indicativo da necessidade de tomar como objeto de pesquisa a prática dos formadores relativas à abordagem temática. Em sintonia com essa ideia, Hunsche (2015), em pesquisa que investigou práticas de formadores de professores da área de Ciências da Natureza na perspectiva da abordagem temática, concluiu, entre outros aspectos, que ainda se fazem necessárias investigações que busquem compreender a influência de trabalhos com abordagem temática não somente na formação e atuação de professores, mas igualmente na prática dos próprios formadores.

No caso de pesquisas que se ocupam das práticas de formadores que exploram a abordagem temática é importante sinalizar os resultados do trabalho de Magoga e Muenchen (2018) que mapearam como uma característica dessa prática a presença da problematização no sentido exposto por Paulo Freire.

Pesquisas que analisam a expressiva produção acadêmica/publicações brasileiras sobre o Ensino de Química, como as de Francisco e Queiroz (2008) e Silva e Queiroz (2016), indicam que aquelas destinadas ao estudo da formação de professores de Química se centram principalmente na formação inicial e na dos docentes da Educação Básica em serviço. Disso conclui-se que o trabalho do professor da Educação Superior, em especial, o formador de professores tem ocupado menos espaço na agenda de pesquisadores brasileiros em Ensino de Química. Por meio do trabalho de Silva e Queiroz (2016) se identifica um crescimento mais recente, ainda que tímido, de trabalhos que debatem sobre o formador de professores de Química.

Neste cenário é importante considerar o exposto por Cruz e Magalhães (2017) que, ao analisarem a aprendizagem construída no contexto de diferentes componentes curriculares associadas à Didática na formação inicial de professores, pontuam que estudantes de licenciatura acreditam ser influenciados pela prática de seus formadores. Somam-se a isso, a constante avaliação que eles próprios fazem, a partir de seus conhecimentos, sobre a atuação do formador (Cruz \& Magalhães, 2017). O destacado por esses autores está em sintonia com a defesa de Freire (1996) de que a docência "exige a corporeificação da palavra pelo exemplo" (p. 34).

Em face ao exposto sobre a importância da problematização na prática dos formadores de professores que tratam da abordagem temática em seus processos educativos, a carência de trabalhos que associam a abordagem temática à prática de formadores, e o caráter incipiente da pesquisa em Ensino de Química a respeito dos formadores de professores, o objetivo deste trabalho foi investigar como se caracterizou a problematização promovida por um formador durante o desenvolvimento de uma proposta de abordagem temática fundamentada nas contribuições de Paulo Freire 
no contexto de um estágio curricular supervisionado na componente curricular Química no Ensino Médio. Entende-se que trabalhos dessa natureza podem colaborar na elucidação de características a serem consideradas por formadores de professores da área de Ciências da Natureza, de modo geral, no desenvolvimento de processos formativos sustentados em pressupostos teórico-metodológicos de Freire. Assim como na sinalização de potencialidades para a pesquisa em Ensino de Ciências da Natureza que contemple a prática desses formadores. Compreende-se, a partir dos trabalhos de Hunsche (2015) e Magoga e Muenchen (2018) que essas são questões que precisam ser estudadas de maneira mais sistematizada. Ademais, destaca-se que a perspectiva de abordagem temática adotada neste trabalho se distingue daquela denominada de temas sociais, de acordo com a caracterização realizada por Santos (2009), em diálogo com a obra de Paulo Freire, e que é amplamente reconhecida e importante no âmbito de Ensino de Química (Caamaño, 2018). Contrariamente da proposta de temas sociais, a abordagem temática adotada em nosso trabalho contempla etapas da investigação temática de Freire (2005).

\section{Abordagem temática e problematização na formação de professores de Ciências da Natureza}

Halmenschlager e Delizoicov (2017) caracterizaram, por meio da análise de publicações em eventos e revistas da área de Ensino de Ciências da Natureza, compreensões variadas de abordagem temática apoiadas em diferentes referenciais teórico-metodológicos. Particularmente a abordagem temática fundamentada nas contribuições teórico-metodológicas de Paulo Freire tem sido caracterizada pela organização curricular via temas geradores e investigação temática (Halmenschlager \& Delizoicov, 2017). Freire (2005) em sua obra Pedagogia do Oprimido descreve a investigação do tema gerador por meio de um processo que Delizoicov $(1982,1991)$ sistematizou e aqui se apresenta sinteticamente assim: (i) levantamento preliminar: consiste na busca de informações em diferentes fontes relativas à realidade local na qual a escola se insere; (ii) análise das situações e seleção das codificações: são examinadas as informações levantadas na primeira etapa que culmina na escolha de situações significativas associadas a contradições constituintes de possíveis situações-limite a serem problematizadas no processo educativo; (iii) diálogos descodificadores: etapa na qual são definidos os temas geradores por meio do diálogo com, nas palavras de Freire (2005), educandos/as e representantes do povo imersos na realidade considerada, de maneira a legitimar as situações significativas previamente selecionadas; (iv) redução temática: ocorre a seleção de conteúdos imperativos à compreensão do tema gerador; (iv) sala de aula: desenvolvimento das atividades com os/as educandos/as no contexto escolar e que foram planejadas previamente.

Investigações no âmbito da formação de professores da área de Ciências da Natureza têm sido realizadas na interlocução teórico-prática com as contribuições supramencionadas. Por exemplo, as pesquisas de Bomfim e Gehlen (2018) e Alves e Silva 
(2015) sinalizam conhecimentos docentes caracterizados por limitações a respeito dos problemas sociais em torno da realidade discente. Pesquisas como a de Sousa et al. (2015) mostram que a realização de trabalhos didático-pedagógicos no âmbito da formação inicial de professores da área de Ciências da Natureza que envolvem o estudo sobre a investigação temática pode colaborar para que licenciandos/as valorizem as "situações reais" dos estudantes da escola, de tal sorte que seus conhecimentos concernentes aos problemas sociais superem uma visão ingênua.

Já no contexto da formação de professores em serviço, Torres et al. (2008) por meio de uma pesquisa puderam apreender que o estudo da investigação temática entre docentes pode favorecer que esses se apropriem de conhecimentos que se distanciam da abordagem puramente conteudista e que pouco auxilia estudantes a interpretarem, de maneira fundamentada teoricamente, os problemas da realidade que os cercam. Esses resultados se aproximam daqueles do trabalho de Sousa et al. (2015).

Também no âmbito da formação de professores em serviço, Sousa et al. (2016) identificaram que as condições de trabalho docentes - o que envolve o mínimo tempo historicamente disponibilizado ao planejamento das atividades - são uma das dificuldades para a concretização do trabalho com temas geradores na escola. Centa e Muenchen (2016) do mesmo modo reconhecem a dimensão temporal de tal trabalho e acrescentam: "participação e transformação da realidade é um processo e, como tal, levase tempo para que efetivas mudanças concretizem-se” (p. 283). Essas autoras articularam as etapas da investigação temática aos três momentos pedagógicos dentro de um trabalho com abordagem temática na formação de professores em serviço. Cumpre registrar que os três momentos pedagógicos (problematização inicial, organização do conhecimento e aplicação do conhecimento) se constituem em uma dinâmica para organizar o trabalho educativo. De acordo com Delizoicov et al. (2002) a problematização inicial busca favorecer a explicitação dos conhecimentos discentes a respeito do tema, bem como problematizá-los. Assim, pode-se colaborar para que discentes tomem consciência de possíveis limitações dos conhecimentos explicitados em comparação com os conhecimentos científicos a serem estudados de forma sistematizada na organização do conhecimento. Na aplicação do conhecimento, por meio de atividades variadas, podemse apreender os conhecimentos apropriados pelos/as estudantes, importantes na análise crítica do tema e/ou outras situações reais (Delizoicov et al., 2002).

No processo formativo com professores da área de Ciências da Natureza promovido por Centa e Muenchen (2016) os três momentos pedagógicos foram estudados como estruturantes do currículo escolar, sendo o primeiro vinculado às três primeiras etapas da investigação temática e a organização do conhecimento e aplicação do conhecimento, respectivamente, à redução temática e ao desenvolvimento em sala de aula.

Os três momentos pedagógicos não devem ser compreendidos como algo estanque, mas como um processo dinâmico em que a problematização, por exemplo, pode permear os diferentes momentos pedagógicos (Solino \& Gehlen, 2015). Ao analisar em que perspectivas docentes utilizam os três momentos pedagógicos, Ferreira 
et al. (2016) realçam que eles são desenvolvidos como metodologia de sala de aula, como estruturante de currículos, em consonância com a abordagem temática defendida por Freire.

Além do sentido exposto no primeiro momento pedagógico, a problematização como aponta Freire (1977):

[...] é a reflexão que alguém exerce sobre um conteúdo, fruto de um ato, ou sobre o próprio ato, para agir melhor, com os demais na realidade.

Não há problematização sem esta última (Daí que a própria discussão sobre o além deva ter, como ponto de partida, a discussão sobre o aqui, que, para o homem, é sempre um agora igualmente) (Freire, 1977, pp. 82-83).

Isso reforça o papel da educação problematizadora de caráter reflexivo defendida por Freire (2005), qual seja, o desvelamento da realidade. Ademais, Freire (1977) sinaliza: "O diálogo problematizador não depende do conteúdo que vai ser problematizado. Tudo pode ser problematizado" (p. 53). Isso sugere que os próprios conteúdos constituintes dos processos de formação docente podem ser problematizados. É essa a perspectiva acerca da problematização adotada em nossa pesquisa. Como destaca Freire (2005; 1977), a educação problematizadora busca a superação daqueles conhecimentos que estão no nível da doxa (mera opinião) por aqueles que estão ao nível dos logos (conhecimentos sistematizados).

$\mathrm{Na}$ literatura se identificam investigações sobre formação de professores no Ensino de Ciências da Natureza que exploram a noção de problematização fundamentada nas contribuições de Paulo Freire. Por exemplo, Gonçalves et al. (2019) ao caracterizarem conhecimentos a respeito das atividades experimentais no Ensino de Química de licenciandos participantes de um processo formação de professores balizado pela problematização na acepção supracitada, sinalizaram para a importância dessa na transformação dos conhecimentos dos licenciandos relativos às atividades experimentais. A necessidade de problematizar - no sentido defendido por Paulo Freire - as atividades experimentais, na qualidade de um conteúdo da formação de professores, também é uma defesa localizada em Gonçalves e Marques (2013).

Portanto, as contribuições de Paulo Freire concernentes à abordagem temática e à problematização têm sido incorporadas de maneira variada por pesquisas em Ensino de Ciências sobre formação de professores.

\section{O contexto do estágio supervisionado de Química}

O desenvolvimento da proposta de abordagem temática durante um estágio supervisionado de Química no Ensino Médio foi descrito em trabalho preliminar (Silveira et al., 2020) que teve como objetivo investigar conhecimentos explicitados por duas licenciandas a respeito dos limites e das potencialidades relativos à abordagem temática realizada em tal contexto. $\mathrm{O}$ estágio supervisionado foi desenvolvido em uma componente curricular (72 horas/aula), prevista para o último semestre de um curso 
de licenciatura em Química de uma universidade pública brasileira. As atividades de estágio na escola se dividiram em um período de observação e outro de regência em dupla. Entre as atividades que antecederam o período na escola, destacam-se a produção de planos de aula e de materiais didáticos e a escrita do projeto de abordagem temática. De forma resumida, destaca-se que as estagiárias lecionaram em dupla 6 horas/aulas, antecedidas de 2 horas/aulas de observação. Contudo, o projeto elaborado totalizava o planejamento de 21 horas/aulas que, por diferentes motivos, não pode ser concretizado em sala de aula. O projeto começou a ser construído em outra componente curricular, em semestre anterior ao estágio, na qual ocorreu a investigação do tema desenvolvido na regência. Essa investigação foi organizada considerando as contribuições de Sousa et al. (2015). Assim como se procedeu no trabalho desses autores, a investigação do tema foi orientada por uma etapa da investigação temática: o levantamento preliminar. Essa etapa foi conduzida pelas duas licenciandas e pelo formador - que também foi o docente responsável em ambas componentes curriculares. A partir da execução dessa etapa foram identificadas problemáticas da comunidade na qual a escola está inserida e cuja análise, conduzida pelas licenciandas em parceria com o formador possibilitou a escolha do tema, qual seja, moradia. Dentro do tema escolhido, foi selecionada a situação significativa tratamento de esgoto para ser explorada no projeto. Na sequência da definição do tema, foram executadas as etapas redução temática e desenvolvimento em sala de aula. Esta última foi promovida por meio da dinâmica dos três momentos pedagógicos (Delizoicov et al., 2002).

Jáse reconheceu em publicação preliminar (Silveira et al., 2020) que a não realização de etapas da investigação temática - especialmente a etapa diálogos descodificadores - pode ter sido uma limitação na apropriação do processo de investigação temática por parte das licenciandas. A própria literatura que aborda o processo de investigação temática na formação de professores reconhece que a obtenção de temas geradores - cumpre registrar que na proposta adotada o tema selecionado não é denominado propriamente de tema gerador - caracterizada pela ausência de determinadas etapas da investigação temática pode ter implicações como a falta de legitimação de situaçõeslimite que afetam uma comunidade (Neres \& Gehlen, 2018). O reconhecimento desse limite é importante, uma vez que uma das contribuições do processo educativo por meio de temas geradores seria o enfrentamento de ditas situações-limite (Freire, 2005). De outra parte, há ainda assim a valorização da literatura relativa ao desenvolvimento da investigação temática com essas características na formação de professores, pois se tem indicativos em resultados de pesquisa que ela pode colaborar para atuação mais crítica de professores na Educação Básica (Neres \& Gehlen, 2018). Outra característica relevante do trabalho realizado é que se conseguiu promover a etapa sala de aula que, de acordo com Neres e Gehlen (2018), é junto com a etapa de codificação e sua análise, a que é menos promovida em processos de formação de professores que executam as etapas da investigação temática. 
Registros sobre o planejamento e desenvolvimento do projeto de abordagem temática vinculado ao estágio supervisionado foram realizados em um diário virtual coletivo inserido na plataforma MOODLE (Modular Object-Oriented Dynamic Learning Environment). Gonçalves et al. (2008) advogam em favor do diário coletivo em processos de formação docente como modo de catalisar a construção de conhecimento reconhecendo a sua natureza social, bem como a exposição dos registros e reflexões.

No diário virtual coletivo se descreviam além de relatos das atividades realizadas na componente curricular, o que incluiu o período de observação e regência na escola, reflexões relacionadas a tais relatos e ao próprio processo de planejamento e avaliação do projeto de abordagem temática.

O diário virtual coletivo foi escrito de forma periódica (semanalmente), por dois meses, e de maneira alternada pelas licenciandas. Assim, por exemplo, para cada intervenção das estagiárias (havia aulas de Química em dois dias da semana) uma delas se responsabilizava pelo registro de relatos da aula desenvolvida e das reflexões decorrentes daquele momento. Cada registro no diário gerava outros, na medida em que o formador e a outra licencianda faziam as suas leituras e compartilhavam suas reflexões, igualmente escritas, de modo a caracterizar a natureza coletiva do diário virtual. Com isso se desencadeava um processo dialógico entre formador e licenciandas. Portanto, o formador e as licenciandas foram os autores de um mesmo diário virtual coletivo. O professor de Química da escola que supervisionou o estágio e uma estagiária de docência de um programa de pós-graduação da área de Ensino de Ciências foram convidados a participarem da escrita do diário e tinham acesso a ele. Ambos participaram ativamente do processo formativo, mas por opção deles não fizeram registros no diário virtual coletivo. Os registros, além de exercerem uma função pedagógica, também se constituíram como fonte de informação qualitativa para a pesquisa, conforme se descreverá a seguir. A produção do diário, portanto, antecedeu a interação com a escola (observação e regência) no âmbito do estágio supervisionado e se estendeu após essa interação. É importante reforçar que a interação com escola iniciou no semestre anterior com o processo de investigação do tema.

A proposta teórico-metodológica adotada no estágio supervisionado se sustenta em Gonçalves et al. (2019). Esses, a partir de uma fundamentação em Freire (1977) a respeito da problematização, propõem uma dinâmica com atividades de explicitação de conhecimentos e de apropriação de novos conhecimentos, sendo essas atividades mediadas pela problematização.

Essa dinâmica permeou todo o processo de orientação do estágio supervisionado e a própria elaboração do diário virtual coletivo.

\section{Os procedimentos de obtenção e análise das informações qualitativas}

Além do diário virtual coletivo ter se constituído como artefato formativo, foi tomado como corpus de análise na pesquisa. Essa dualidade do diário é endossada por 
Zabalza (2004) ao defender a validade do diário como instrumento de pesquisa. O autor destaca que o problema validade/representatividade da amostra direcionado ao diário se insere na discussão atual relativa à pesquisa qualitativa, de modo geral. A respeito dessa questão, Minayo (2017), por exemplo, ressalta que os pesquisadores qualitativos ainda que precisem amiúde justificar a composição dos participantes da investigação, inclusive do ponto de vista quantitativo, o que deve se sobressair é a lógica interna do objeto de sua pesquisa.

Na pesquisa em Ensino de Ciências não raramente se identificam investigações focadas em um único sujeito de pesquisa - assim como neste trabalho - , a exemplo daquelas de Moro et al. (2015) e de Oliveira e Mortimer (2020). De modo a reforçar que a constituição da amostra em uma pesquisa é um aspecto complexo e que se relaciona mais com o escopo da pesquisa do que com o atendimento a regras numéricas.

O diário virtual coletivo foi submetido às três etapas da análise textual discursiva (Moraes, 2003):

- unitarização: a partir da leitura do diário virtual coletivo, orientada pelos pressupostos teóricos previamente explicitados, foram extraídos fragmentos (unidades de análise) cujo exame possibilitou atingir o objetivo do trabalho. Assim, foram analisados todos os registros do formador no diário virtual coletivo.

- categorização: as unidades de análise extraídas na etapa anterior foram classificadas em categorias. Entre as opções de categorias (a priori, emergentes ou mistas) foram empregadas as emergentes. Ao contrário das categorias $a$ priori, que são definidas antes propriamente do processo de análise a partir do referencial explícito da pesquisa, as emergentes são construídas diretamente das unidades de análise. Contudo, cumpre registrar que isso não significa uma análise sob um vácuo teórico ou uma ausência de referencial teórico. $O$ oposto apoiaria a visão da neutralidade no processo interpretativo, equívoco que dispensa maior argumentação. Como destacam Moraes e Galiazzi (2007) "a emergência [...] não é um brotar de algo, mas uma reconstrução do pesquisador a partir de compreensões teóricas já existentes” (p. 127). Assim, a elaboração das categorias nesta pesquisa se baseou não somente em pressupostos teóricos explicitados previamente, mas também em outros pressupostos tácitos dos autores. As categorias foram assim denominadas: o respeito ao conhecimento das licenciandas; e a consciência do inacabamento na docência. Ao se considerar a validade das categorias como uma característica essencial da análise, destaca-se, de acordo com Moraes e Galiazzi (2007), que a validade teórica das categorias emergentes é construída gradualmente e não está dada previamente à análise.

- comunicação: etapa em que ocorre a produção de metatextos descritivos e interpretativos com base na realização das etapas anteriores. Unidades de análise são apresentadas no metatexto, de modo a favorecer a validação das categorias e interpretações, de acordo com o que expõe Moraes e Galiazzi (2007). 
Reconhece-se que a análise textual discursiva está em sintonia epistemológica, no que concerne à possibilidade do conhecimento - que discute por meio de diferentes posições se o sujeito é realmente capaz de apreender o objeto -, com os pressupostos teórico-metodológicos de Paulo Freire (Gonçalves, 2020). Ambos se afastam do relativismo na qualidade de posição filosófica para a qual a verdade é relativa ao contexto. Sabidamente o relativismo é constituído de uma contradição, uma vez que ao defender que toda verdade é relativa ao contexto, atribui também à sua formulação um caráter relativo. De forma sintética, registra-se que o reconhecimento desta coerência epistemológica entre a análise textual discursiva e os pressupostos teóricometodológicos de Paulo Freire é fundamental para que os referenciais metodológicos adotados na pesquisa não impliquem em uso reducionista de puros procedimentos, conforme destacam Santos e Greca (2013).

Ademais a análise textual discursiva foi utilizada neste trabalho como constituinte de um processo de comunicação. Gonçalves (2020), sustentado pela aproximação de natureza epistemológica entre a análise textual discursiva e os pressupostos teóricoepistemológicos de Paulo Freire, propõe que a primeira pode ser explorada como constituinte de um processo de comunicação a partir da compreensão educativa de Freire (1977). A educação como um processo de comunicação é proposta por Freire (1977) em oposição à ideia de extensão para a qual ocorreria a suposta transmissão de conhecimentos por parte daqueles/as que seriam os seus/suas detentores/as às pessoas cujas cabeças estariam vazias de conhecimentos e os pudessem passivamente acolher. No entanto, para esse autor:

[...] educar e educar-se, na prática da liberdade, é tarefa daqueles que sabem que pouco sabem - por isto sabem que sabem algo e podem assim chegar a saber mais - em diálogo com aqueles que, quase sempre, pensam que nada sabem, para que estes, transformando o seu pensar que nada sabem em saber que pouco sabem, possam igualmente saber mais (Freire, 1977, p. 25).

A partir disso se apreende tanto uma crítica tácita de Freire (1977) a uma visão relativista no processo educativo, como um entendimento de comunicação orientador de tal processo. Balizado por esse entendimento, Gonçalves (2020), defende que a análise textual discursiva utilizada na pesquisa em parceria entre formador/pesquisador em Ensino de Ciências e licenciandos/professores em serviço possa ser constituinte de um processo de comunicação na acepção de Freire (1977). Nessa compreensão de pesquisa em parceira não cabe encerrar a participação de qualquer integrante a ações pontuais como a de transcrever entrevistas ou aplicar instrumentos para coleta de informações a serem examinadas e reservar aos integrantes mais experientes do grupo a análise, de tal sorte que posteriormente esses possam supostamente transferir aos demais os conhecimentos sistematizados.

Aliás, a pesquisa na docência é defendida por Freire (1996) como algo necessário à prática educativa. Sobre a possibilidade de participação ativa dos investigados no processo de pesquisa, Freire (1981) expõe uma compreensão: 
Para muitos de nós, a realidade concreta de uma certa área se reduz a conjunto de materiais ou de fatos cuja existência ou não, de nosso ponto de vista, importa constatar. Para mim, a realidade concreta é algo mais que fatos ou dados tomados mais ou menos em si mesmos. Ela é todos esses fatos e todos esses dados e mais a percepção que deles esteja tendo a população envolvida. Assim, a realidade concreta se dá a mim na relação dialética entre objetividade e subjetividade.

[...] Dizer que a participação direta, a ingerência dos grupos [...] no processo de pesquisa altera a "pureza" dos resultados implica na defesa da redução daqueles grupos a puros objetos da ação pesquisadora de que, em consequência, os únicos sujeitos são os pesquisadores profissionais. Na perspectiva libertadora em que me situo pelo contrário, a pesquisa como ato de conhecimento tem como sujeitos cognoscentes, de um lado, os pesquisadores profissionais, de outro, os grupos [...] e, como objeto a ser desvelado, a realidade concreta (Freire, 1981, p. 35).

Apesar de Freire (1981) não estar se referindo propriamente à pesquisa em parceria entre formadores e professores em formação inicial ou em atuação na escola, ele expressa um entendimento sobre o papel do pesquisador e da pesquisa que colabora para se advogar em favor da pesquisa a respeito da própria prática desenvolvida em parceria entre formador e professores em formação inicial ou em atuação na escola.

Em suma essa compreensão de pesquisa sustentou o trabalho apresentado aqui, sendo que pautou o modo como a análise textual discursiva foi utilizada, constituindose como integrante de um processo de comunicação, na acepção de Freire (1977). Logo, o formador e licenciandas que produziram o diário virtual coletivo, o analisaram após o encerramento da componente curricular de estágio supervisionado e são autores ${ }^{1}$ deste trabalho. Com base na defesa de Freire (1996) da pesquisa na docência - que constitui uma visão ampliada a respeito do papel da pesquisa, portanto, para além de questões de ordem metodológica em uma investigação - articulada à proposição da análise textual discursiva como constituinte de um processo de comunicação (Gonçalves, 2020), entende-se que o exame de informações qualitativas em uma pesquisa pode contemplar explicitamente um ato educativo entre pesquisadores em Ensino de Ciências e professores em atuação ou em formação inicial. Assim, a visão teórica de Freire (1981, 1996) concernente ao papel da pesquisa pode influenciar no próprio modo como a análise textual discursiva é realizada. Isso remete à ideia de que os pressupostos teóricos, explícitos ou tácitos, explorados pelos pesquisadores na análise textual discursiva desempenham mais do que a função de proporcionar a unitarização, a categorização e a construção de metatextos, uma vez que podem orientar o entendimento e a promoção destas etapas da análise textual discursiva. É nisso que se sustenta a compreensão da análise textual discursiva como constituinte de um processo de comunicação. Enfim, a utilização da análise textual discursiva no âmbito da pesquisa do professor está em sintonia com a

1 A submissão do diário virtual coletivo à análise foi precedida pelo consentimento de todos os seus elaboradores. Além da etapa de geração das informações qualitativas, os autores participaram igualmente nas demais etapas da pesquisa que envolveu a análise dessas informações e produção deste artigo. 
defesa de Freire (1996), bem como com os pressupostos deste procedimento analítico, que tem na sua qualidade política, o objetivo de intervir nos discursos que analisa e na própria realidade (Gonçalves, 2020).

É certo que na literatura se encontra a defesa ampla, sob diferentes abordagens teórico-metodológicas, da perspectiva do professor-pesquisador de sua própria prática, a exemplo do exposto nos trabalhos de Maldaner (2000) e Galiazzi (2003). Também é possível localizar na literatura pesquisas - igualmente sob diferentes abordagens teórico-metodológicas - conduzidas em parceria entre pesquisadores e professores em formação inicial. São exemplos dessas pesquisas o exposto por Spelta et al. (2012) e Silva et al. (2020). Reconhece-se que o presente trabalho se insere neste cenário mais amplo de investigações.

\section{Análise das informações qualitativas}

\section{0 respeito ao conhecimento das licenciandas}

Ainda que a componente curricular do curso de licenciatura em que atua o formador tenha conteúdos pré-estabelecidos que constituam o processo formativo, há outros que foram selecionados pelo formador a partir dos conhecimentos que eram explicitados pelas licenciandas, sejam por meio da regência, seja por meio da escrita no diário virtual coletivo. Isso remete à necessidade de relacionar os conhecimentos que constituem o currículo com a experiência social que os alunos trazem consigo, como destaca Freire (1996). No caso do estágio supervisionado é importante considerar a experiência que as/os licenciandas/os possuem e/ou constroem durante o estágio.

Assim, no relato a seguir, o formador a partir da apreensão da experiência vivenciada pelas licenciandas, propõe uma reflexão sobre um conteúdo para docentes em Química: as atividades experimentais. Esta reflexão não é exposta como uma doação de ideias às licenciandas, mas como um convite a exporem a sua reflexão, de modo que cada participante possa explicitar suas ideias:

[...] Assim, pensando mais uma vez que podemos rever as atividades que realizamos e considerando o comentário da [A] (talvez precisa-se trabalhar melhor o envolvimento do grupo para executar o experimento sem causar tumulto"), sugiro que a partir da referência supracitada vocês podem apresentar uma reflexão fomentada pelas questões: Vocês acreditam que o exposto nesta referência poderia nos ajudar a revisar o planejamento das atividades experimentais? Caso afirmativo, como? Teriam outras sugestões? Como poderíamos fazer isto no caso do plano de aula da atividade experimental? (F)

Entende-se que o exposto apresenta uma característica da problematização discutida por Freire (1977), isto é, a problematização não deve se restringir aos conhecimentos sistematizados. Nas palavras de Freire (1977) o "conhecimento experiencial" também é objeto de problematização na perspectiva dialógica defendida 
pelo autor. Ao discutir a incidência do diálogo sobre o conhecimento sistematizado ou o conhecimento experiencial, Freire (1977) salienta que o objetivo desse diálogo: "é a problematização do próprio conhecimento em sua indiscutível reação (sic) com a realidade concreta na qual se gera e sobre a qual incide, para melhor compreendê-la, explicá-la, transformá-la" (p. 52). A valorização de certos conhecimentos experienciais de acordo com a realidade das licenciandas possibilita contemplar no processo formativo conhecimentos sistematizados que dialogam com aqueles que as licenciandas trazem consigo. Nessa direção, o exposto está em consonância com Fernandes (2016) que, apoiada em parte nas contribuições teórico-metodológicas de Freire, defende a formação de professores de Química - e o desenvolvimento profissional dos seus formadores - a partir da escola de Educação Básica na qualidade de um espaço formativo.

Registros das licenciandas sobre diferentes momentos do projeto desenvolvido no estágio supervisionado puderam ser problematizados. A seguir um trecho relativo ao planejamento:

Li o registro do que fizemos por meio das escritas da [A] e da [B] [...] penso que estes trechos ajudam também a recuperar um pouco do que foi o projeto inicialmente. E na sequência faço alguns comentários [...] Seguem os trechos:

\section{$[\ldots]$}

Durante os processos de investigação temática [na realidade gostaria de registrar que não fizemos de fato uma investigação temática - já fiz este comentário no projeto], percebeu-se a importância de trabalhar com a temática moradia, que mostrou-se significativa para ser explorada didaticamente.

\section{$[\ldots]$}

Também foram analisados reportagens e trabalhos acadêmicos que relatassem os problemas pertinentes à comunidade. Desta forma, foi possível definir o tema gerador [na realidade gostaria de registrar que não é um tema gerador propriamente - na minha interpretação] para o trabalho. A partir da definição, os conteúdos e as atividades que irão ser desenvolvidas no projeto foram realizados. (F)

No caso descrito, o formador se refere aos conhecimentos explicitados pelas licenciandas sobre o projeto elaborado e a respeito da investigação temática que, conforme explicitado preliminarmente, não contemplou as cinco etapas. Deste modo, o formador expõe uma reflexão acerca do rigor das expressões investigação temática e tema gerador. Interpreta-se que essa reflexão pode colaborar para o reconhecimento dos limites do processo desenvolvido, de maneira a favorecer a apropriação de conhecimentos sobre a abordagem temática fundamentada em Paulo Freire. Cumpre registrar, no entanto, que a forma como foram utilizadas as etapas da investigação temática tem sido considerado como uma "adaptação" das etapas de investigação temática (Sousa et al., 2015). Sousa et 
al. (2015) ao adotarem esta perspectiva de "adaptação" das etapas da abordagem temática durante atividades didático-pedagógicas em um estágio supervisionado em Física no Ensino Médio, também não utilizam a expressão tema gerador para se referirem ao tema obtido. Seja como for, concordamos com Fernandes et al. (2016) de que a formação inicial de professores da área de Ciências da Natureza precisa romper com as práticas extensionistas - caracterizadas por Freire (1977) - que perpetuam a pura exposição de conteúdos, dicotomizando-os dos conhecimentos que estudantes trazem consigo para o processo educativo.

A valorização recorrente das ideias explicitadas pelas licenciandas enaltece a dialogicidade no processo formativo. Na medida em que as licenciandas expressam suas compreensões a respeito das experiências vivenciadas no estágio podem conjuntamente com o formador refletir sobre suas práticas docentes. Nisso é importante considerar o exposto por Freire (1992) sobre a docência: "Quanto mais tolerantes, quanto mais transparentes, quanto mais críticos, quanto mais curiosos e humildes, tanto mais assumem autenticamente a prática docente" (p. 81). As reflexões compartilhadas pelo formador e pelas licenciadas são interpretadas como constituintes da problematização que podem favorecer que as pessoas envolvidas no processo formativo assumam, de forma autêntica como destaca o autor, a prática docente.

Em outro momento, caracteriza-se o incentivo para as reflexões por meio de posicionamento diante de indagações que sugerem a necessidade de constantemente se apropriar de novos conhecimentos:

Fiz alguns questionamentos para fomentar o debate no que concerne à realização do trabalho em grupo e das atividades experimentais. Naqueles questionamentos que propus já está implícita a minha opinião sobre como poderíamos enfrentar os problemas (a indicação de referências foi neste sentido). E por isso não escrevi mais, porém posso fazer se considerarem necessário. $(\mathrm{F})$

A busca frequente pelos conhecimentos das licenciandas reflete uma das características da problematização que é favorecer a apreensão dos conhecimentos discentes. Esses questionamentos que constituem parte de um processo de problematização se opõem à invasão cultural. É importante, portanto, não apenas a transformação da realidade como dos conhecimentos que as licenciandas e formador trazem consigo. Segundo Freire (1977) é isso que caracteriza, em parte, ser dialógico.

O formador ao fomentar a explicitação do conhecimento das licenciandas sobre possibilidades acenadas por ele dá indicativos de reconhecer, como indicado por Freire (1977) o caráter dialético da problematização: "Vocês podem discordar e sinalizar novas possibilidades, afinal estamos aprendendo juntos" (F). Formador e licenciandas podem explicitar seus conhecimentos que podem constituir níveis distintos de autonomia e consciência sobre o processo educativo, a abordagem temática ou outros assuntos que perpassam o estágio. E assim se educam em comunhão. Ao discutir a acepção de problematização, Freire (1977) destaca que o aluno que se entende como um puro "receptor" de conteúdos inibe sua potencialidade para pensar e se reduz a um 
repetidor de conteúdos. Identifica-se na escrita em discussão do formador exatamente um entendimento contrário de desafiar as licenciandas a pensarem e exporem o que pensam, valorizando que elas assumam a docência de forma autêntica e autônoma. Para isso, valoriza a reflexão em torno do processo formativo, rompendo com características da cultura do silêncio, a exemplo da autodesvalia, quando deixam de apresentar suas reflexões e supervalorizam a fala do educador. De acordo com Freire (2005) a pedagogia como humanizadora e libertadora caracteriza-se pelo desvelamento do mundo da opressão e o comprometimento com a práxis. Algo enaltecido no processo formativo. Para além disso, teríamos a transformação da realidade opressora, em um processo de permanente libertação, em que alguns traços são aqui realçados. Como pontuou Freire (1977): "[...] nenhum pensador, nenhum cientista elaborou seu pensamento ou sistematizou seu saber científico sem ter sido problematizado, desafiado" (p. 54). Reflexões dessa natureza são compartilhadas de uma maneira recorrente pelo formador:

[...] ao longo dos anos em que tenho utilizado o diário há em alguma medida dificuldades no que dizem respeito à utilização dele. Às vezes o diário é interpretado mais como um instrumento de descrição do que foi feito (o que é muito importante em minha avaliação, pois nos permite reflexões futuras acerca do que fizemos) e menos de uma discussão mais sistematizada do que fizemos. Apesar de refletirmos nem sempre registramos nossas reflexões, de modo a compartilhar com os colegas nossos posicionamentos, opiniões. E entendo que podemos ter justificativas diversas para isto [...] (F)

Sobre o exposto é importante considerar o que Freire (2008) denomina de visão mágica da palavra escrita e que precisa ser superada. O autor ao discutir a leitura, questiona uma compreensão dessa que caracteriza a sua qualidade pelo número de páginas lidas e não propriamente pela natureza da leitura. Freire (2008) sugere que posicionamento semelhante se aplica à atividade correlata da leitura: a escrita. A qualidade da escrita não está associada à quantidade de páginas escritas. Assim, ao formador propor a necessidade de compartilhar reflexões por meio da escrita, para além da descrição de um ato educativo, contempla esse aspecto mencionado por Freire (2008) e problematiza o próprio conhecimento inicial que as licenciandas podem ter sobre o ato de escrever em um processo formativo. Em outros termos, a problematização do formador se caracteriza por respeitar os conhecimentos que as licenciandas têm a respeito da abordagem temática e de outros assuntos educacionais a ela vinculados, bem como acerca de conhecimentos mais tácitos como aqueles relativos às características escrita em diário virtual coletivo e o seu papel e que podem influenciar na condução da dinâmica adotada pelo formador. A escrita no diário virtual coletivo também pode se constituir em conteúdo tácito da formação inicial e, portanto, também foi um objeto de problematização. 
Para as dificuldades que tenham sido apenas relatadas pelas licenciandas, o formador as problematizou:

Um aspecto que com frequência socializo com quem trabalho é a necessidade que temos de ter compromisso com a nossa crítica e nossa avaliação. Se identificamos dificuldades é preciso em alguma medida apontar modos de enfrentá-las, bem como desenvolver ações para enfrentá-las em dado momento. Por vezes neste diário sugeri que por meio de determinada leitura pudéssemos refletir sobre possibilidades de enfrentarmos problemas que identificamos. (F)

Freire (1996) destaca que o processo educativo não é um ato de treinar e depositar conhecimentos e o exposto pelo formador parece estar em harmonia com o entendimento do autor. Freire (1996) ressalta ainda a importância das experiências estimuladoras para tomada de decisões e da responsabilidade de ensinar, com liberdade e autoridade. $\mathrm{O}$ autor aponta que o professor não pode ser imparcial em suas atitudes. É preciso explicitar o que pensa, o que acredita, de modo a favorecer que o/a discente possa identificar o caminho que deseja seguir. Valorizando a corporeificação da palavra pelo exemplo, como sugere Freire (1996), é que as licenciandas podem desenvolver sua autonomia e autenticidade no processo formativo.

Em suma, nesta categoria se identificou que a problematização se caracterizou pelo respeito aos conhecimentos das licenciandas. Isso é coerente com o que expõe Freire (1977) sobre uma característica da problematização, qual seja, superar a ideia de que há detentores/as do conhecimento a doar a desprovidos/as. Nesse processo que se caracteriza pela sua dialogicidade é possível pontuar que a problematização não se restringiu aos conhecimentos sistematizados, mas se direcionou igualmente àqueles de natureza "experiencial". A constante valorização da explicitação dos conhecimentos das licenciandas vai na direção de apreendê-los e, juntamente com os conhecimentos do formador que são explicitados, caracterizam os diferentes níveis de consciência contemplados no processo formativo. Os diálogos entre eles podem possibilitar a reconstrução de conhecimentos discentes e docentes e o desenvolvimento da autonomia e criticidade em torno do exercício da docência.

\section{A consciência do inacabamento na docência}

Como já mencionado, as licenciandas foram incentivadas pelo formador a refletirem sobre o planejamento e desenvolvimento do projeto. Na interlocução com essas reflexões o formador compartilhava outras que serão caracterizadas nesta categoria como associadas à consciência do inacabamento da docência. A seguir destaca-se um exemplo a partir dos relatos das licenciandas concernente às atividades com estudantes da escola:

Penso que as reflexões trazidas pela $[\mathrm{B}]$ e a $[\mathrm{A}]$ são importantes para a revisão do planejamento. [...] Seria ótimo, em minha opinião, se pudéssemos após cada aula ao expor as reflexões inserir aqui o plano de aula como possíveis 
modificações no texto indicando o que se faria de diferente para enfrentar os problemas identificados. [...] Acredito que a utilização de estratégias/métodos de aprendizagem cooperativa para o trabalho em pequenos grupos poderia nos ajudar a favorecer uma maior participação dentro dos grupos. (F)

A reflexão exposta pelo formador possui um caráter problematizador a respeito da prática de ensino promovida na escola. É apresentada uma reflexão para repensar o trabalho em pequenos grupos nas aulas de Química. Considerando o trabalho em grupo dentro da perspectiva da abordagem temática pautada nas contribuições de Freire, é essencial que essa estratégia valorize a interação entre os sujeitos e a explicitação de seus conhecimentos. O trabalho em pequenos grupos a partir das contribuições da aprendizagem cooperativa busca favorecer a interação entre todos os membros do grupo, de modo a superar características de grupos em que uma parcela de integrantes assume as responsabilidades e tarefas de todo o grupo (Bonals, 2003). Para valorizar a interação social, algumas características são imprescindíveis, como o respeito (Bonals, 2003). Essa característica dialoga com a visão de educação defendida por Freire (1996) que realça o respeito ao conhecimento discente como uma necessidade da docência. Considerada como uma estratégia de aprendizagem mais complexa do que a individualista ou competitiva, por exemplo, a cooperativa valoriza dimensões para além daquela conceitual no processo formativo dos sujeitos. Em suma, as reflexões do formador sobre as estratégias/métodos de aprendizagem cooperativa para o trabalho em pequenos grupos que são reconhecidamente importantes, de acordo com o exposto na literatura, remetem à necessidade da constante tomada de consciência do inacabamento que precisa constituir a docência, como destaca Freire (1966). Para o autor a mudança na prática docente é algo que deve perdurar. Em suas palavras: "Daí que insista na problematização do futuro e recuse sua inexorabilidade” (p. 53). Essas reflexões se referem às atividades realizadas no segundo momento pedagógico (organização do conhecimento). Conforme destacam Delizoicov et al. (2002), neste momento podem ser utilizadas atividades diversas para ensinar sobre os conhecimentos selecionados. Contudo, o formador também dirigiu reflexões para atividades que constavam no terceiro momento pedagógico:

Penso que os experimentos planejados por vocês têm algumas características que defendo, por exemplo, a utilização de materiais de baixo custo e que não trazem risco à integridade física dos alunos. Por outro lado, não tivemos tempo para estudar sobre como organizar metodologicamente atividades experimentais. Durante o semestre deveria ter sugerido para vocês a leitura do primeiro capítulo [...] e de alguns experimentos que seguem no capítulo 2 como exemplares. Isto poderia ter nos ajudado na organização desta atividade experimental.

Assim, pensando mais uma vez que podemos rever as atividades que realizamos e considerando o comentário da [A] ("talvez precisa-se trabalhar melhor o envolvimento do grupo para executar o experimento sem causar tumulto”), sugiro 
que a partir da referência supracitada vocês podem apresentar uma reflexão fomentada pelas questões: Vocês acreditam que o exposto nesta referência poderia nos ajudar a revisar o planejamento das atividades experimentais? Caso afirmativo, como? Teriam outras sugestões? Como poderíamos fazer isto no caso do plano de aula da atividade experimental? (F)

Ao compartilhar reflexões sobre a realização das atividades experimentais e fomentar que as licenciandas explicitem outras reflexões sobre o assunto, o formador colabora para a tomada de consciência das licenciandas concernente ao inacabamento de seus conhecimentos a respeito das atividades experimentais. Assim como do próprio formador a respeito de como conduzir o estudo das atividades experimentais a serem promovidas naquele contexto de estágio supervisionado.

As atividades diversas na organização do conhecimento podem ser igualmente promovidas no terceiro momento pedagógico (aplicação do conhecimento) que também se dedica à compreensão do conhecimento que é apropriado pelos estudantes. $\mathrm{O}$ emprego dessas atividades diversas justifica a necessidade do estudo por parte dos professores de atividades e recursos variados podendo ser utilizados no processo de ensino e aprendizagem de Ciências, para além da dinâmica de trabalho em pequenos grupos e o desenvolvimento de atividades experimentais pontuadas. Subjacente a isso está a compreensão de que abordagem temática com fundamentação nas contribuições de Freire prevê a interlocução com conhecimentos mais amplos das áreas de educação e de Ensino de Ciências, sem obviamente negligenciar a necessidade de coerência entre a perspectiva teórico-metodológica de Paulo Freire com aquelas que sustentam as propostas de atividades realizadas.

Ademais, é certo que, como docentes, ao mesmo tempo em que privilegiamos determinados conhecimentos, igualmente excluímos outros (Delizoicov et al., 2002). Todavia, a reflexão sobre o planejamento das atividades experimentais pelas licenciandas orienta a continuidade da construção de conhecimentos concernentes ao assunto no exercício da profissão. Considerando as atividades experimentais dentro da perspectiva da abordagem temática pautada nas ideias de Freire, é imperativo que essas se afastem de uma visão bancária de educação. Por exemplo, as atividades experimentais centradas na execução de procedimentos pelo professor e na sua exposição oral se aproximam dessa visão de educação, bem como aquelas que reduzem o papel das atividades experimentais a uma simples comprovação do conhecimento teórico previamente estudado. Em face do exposto, justifica-se a necessidade de submeter professores em formação inicial a discussões contemporâneas a respeito das atividades experimentais, de modo que esses possam promover experimentos na escola que se distanciem de uma visão bancária de educação.

É importante destacar que há trabalhos que buscam aproximar a discussão a respeito das atividades experimentais de ideias associadas às contribuições de Freire. Nesta direção há como exemplo o trabalho de Francisco Júnior et al. (2008) que se apóiam nos três momentos pedagógicos (Delizoicov et al., 2002) para organizar a 
dinâmica de uma proposta de atividade experimental problematizadora. Outro exemplo é o trabalho de Gonçalves e Marques (2013) em que se caracterizam, em interlocução com formadores de professores de Química, situações-limite vinculadas ao processo de disseminação de conhecimentos acerca de atividades experimentais, fundamentados teoricamente, no desenvolvimento profissional deles.

As reflexões de caráter problematizador do formador não se reduziram ao ato educativo das licenciandas, mas também às dificuldades que envolveram o projeto:

Aqui neste trabalho eu diria que influenciados pelas etapas do processo de investigação temática e por outras ideias de Paulo Freire e seus interlocutores nós construímos etapas para investigar o tema, bem como selecionar os conteúdos em interlocução com o professor da escola, já que estamos em um contexto de estágio [...] Os desafios desde então foram muitos e posso escrevê-los mais adiante no diário a partir das minhas compreensões. (F)

O reconhecimento dos desafios referentes à abordagem temática fortalece a ideia de que a execução de etapas do processo de investigação temática não é um processo mecânico e linear em que se atingem resultados previamente esperados. $\mathrm{O}$ oposto significaria reduzir potencial humanizador da investigação temática e suas etapas (Milli et al., 2018). Ainda de acordo com Milli et al. (2018) a etapa de levantamento preliminar, por exemplo, exige da equipe de investigadores uma compreensão crítica da realidade dos sujeitos, para os quais a atividade educativa se direciona. Os autores propõem que o emprego da análise textual discursiva pode ser um modo de favorecer a análise das informações obtidas no levantamento preliminar da realidade, uma vez que essas informações por si só não caracterizam essa etapa da investigação temática. A natureza da sistematização adotada para examinar as informações que dispunham as licenciandas e o formador talvez possa explicar, em parte, certos desafios vivenciados. Por outro lado, o contexto de estágio supervisionado em que de fato não se realizou todas as etapas da investigação temática sugere a necessidade de se investigar como os/as lienciandos/ as juntos aos seus/suas formadores/as podem analisar as informações relacionadas à realidade da comunidade. Por fim, entende-se que a reflexão compartilhada pelo formador possa colaborar para que as licenciandas também reflitam a respeito da forma como estavam conhecendo e assim reconheçam a necessidade de conhecer melhor o projeto, em outras palavras, "ad-mirar" o projeto a partir do "admirado" (Freire, 1977).

O formador expõe os desafios derivados desse processo na qualidade de uma reflexão de caráter problematizador:

A interlocução inicial com moradores e alunos por meio do questionário parece não ter sido suficiente para nos auxiliar na identificação de situações significativas. Parece que aquilo que Paulo Freire chamava de "consciência ingênua" pode influenciar na resposta dos sujeitos aos questionários, entre outros aspectos. De modo que, a identificação da temática precisou dialogar com outras fontes e ficamos várias aulas para identificar um tema (moradia) e uma situação 
significativa a ser trabalhada (esgoto). Por outro lado, esta dificuldade implicou em aprendizagens como aquela associada no processo de escolha de um tema a ser explorado em uma situação de estágio supervisionado em interlocução com a realidade local dos estudantes. (F)

A abordagem temática desenvolvida no estágio envolve considerações a respeito das contradições sociais. No entanto, a compreensão da gênese do problema não é tarefa fácil (Almeida \& Gehlen, 2019). No contexto do estágio supervisionado havia somente a componente curricular Química, enquanto que seria desejável, senão imperativo dentro de uma perspectiva de educação defendida por Freire (2005), a presença de uma equipe cujos integrantes tenham formações em diferentes áreas de conhecimento, incluindo aquelas que compõem o currículo escolar. No entanto, isso não descaracteriza obrigatoriamente a potencialidade da abordagem temática adotada no estágio supervisionado. Magoga e Muenchen (2020), apoiados na literatura, chamam a atenção para dificuldades em processos educativos da abordagem temática pautada em Freire e salientam a incorporação de práticas interdisciplinares como uma dessas dificuldades.

A reflexão sobre questões contraditórias que poderiam subsidiar a abordagem temática foi algo recorrente. Como identificá-las e contemplá-las foi algo descrito no diário, como se analisa no trecho que segue:

Um dos aspectos registrados aqui no diário diz respeito à dificuldade para a apreensão de informações associadas à realidade dos estudantes. Um diálogo com uma colega de trabalho me possibilitou algumas reflexões que talvez pudessem gerar encaminhamentos de modo a pelo menos minimizar nossas dificuldades em relação à apreensão de informações associadas à realidade dos estudantes. Uma destas ações poderia ser solicitar aos estudantes que fotografassem aspectos do bairro no qual estão inseridos e que eles caracterizam como positivos e como negativos. Certamente este processo de fotografar precisaria ser feito com os devidos cuidados e com base em orientações docentes. (F)

A reflexão constante sobre a própria prática é uma das defesas de Freire (1977). Segundo ele, quanto mais nos envolvemos na ação e reflexão da realidade, mais próximo estaremos do seu desvelamento que precisa ser construído em um processo dialógicoproblematizador entre educador e educando - na terminologia do autor. Deste modo, para Freire (1977) a visão de mundo dos educandos é necessária ser apreendida, porque nela estão contidos os "temas geradores". A investigação de tais temas e a ação educativa que se estabelece após a identificação deles constituem situação gnosiológica de um mesmo processo (Freire, 1977). Depreende-se, portanto, que a reflexão do formador dialoga com essa compreensão de Freire a respeito da interlocução com os conhecimentos discentes sobre sua realidade e como ela se relaciona com o conteúdo programático a ser construído. Disso se extrai que esse processo é dinâmico e que nossos conhecimentos concernentes a ele também são lacunares e passíveis de revisão e ampliação. O próprio 
Freire (1977) reconhece que a compreensão da realidade não advém de atividades estanques, uma vez que a compreensão da realidade favorecida pelo ato dialógico problematizador colabora para a investigação de novas temáticas.

Ainda sobre as reflexões direcionadas ao planejamento do projeto no contexto de estágio, destaca-se:

A articulação do tema com os conteúdos previstos no planejamento escolar também foi um grande desafio que parece que conseguimos enfrentar inicialmente com o diálogo com os chamados "conceitos unificadores": transformações, energia, escala e regularidades. $\mathrm{O}$ conceito de $\mathrm{pH}$, previsto inicialmente no planejamento escolar, que se associa ao conceito de escala, nos ajudou neste processo de seleção dos conteúdos. Cabe registrar a grande abertura do Professor [D] para a inserção de novos conteúdos não previstos inicialmente no currículo. Isto foi muito importante para o projeto. (F)

Apesar de Freire defender a sujeição dos conteúdos programáticos ao tema, cumpre registrar que no contexto do estágio supervisionado o professor de Química da escola já possuía um planejamento. Contudo, esse professor não apresentou objeção a outros conteúdos para além daqueles que foram inicialmente selecionados e que se tornaram imprescindíveis para a compreensão da realidade contemplada no projeto. Realça-se nessa direção, a autonomia do educador como sujeito crítico no processo de escolha dos conhecimentos em diálogo com os estudantes no processo formativo. Algo que está na direção de superações atreladas ao apego docente aos conteúdos conceituais (Freire, 2005). Nesse contexto é possível apreender a problematização do formador ao apego a um possível conteúdo programático estruturado a partir de conteúdos conceituais. Além disso, o desafio explicitado pelo formador sinaliza que o conhecimento a respeito de como promover a interlocução entre conteúdos previamente selecionados pelo professor da escola com aqueles advindos de um processo de investigação do tema é algo em construção.

$\mathrm{Na}$ mesma direção, o formador reflete sobre limitações na orientação das licenciandas:

[...] pode parecer um contrassenso, mas na qualidade de formador encontro dificuldades para orientar os estagiários (estagiárias). Aqui neste projeto eram duas licenciandas. Estas dificuldades começam antes mesmo do processo de desenvolvimento do projeto, isto é, no seu planejamento. Aliás, parte das dificuldades sinalizadas aqui pode ser em decorrência destas dificuldades de orientação. Iniciamos um projeto inédito para uma situação de estágio e com isto surgem muitas perguntas para as quais o orientador não tem resposta. De maneira que a frequência com que compartilhei dúvidas com a licenciandas foi muito elevada. Parece que sempre falta tempo para aprofundarmos em leituras e discussões necessárias que colaborariam com o planejamento e desenvolvimento do projeto. É sempre uma corrida contra o tempo para iniciar o estágio em data 
prevista e às vezes fica a sensação que planejamos o melhor que conseguimos fazer e não obrigatoriamente aquilo que gostaríamos de ter planejado. (F)

Nesse caso o formador explicita a consciência da inconclusão da docência. Em outras palavras, o processo formativo em ênfase foiinterpretado pelo formador em sintonia com as ideias defendidas por Freire (2005). Como descreve Freire (1996), a possibilidade de intervir, comparar, ajuizar, romper, escolher é o que caracteriza a inconclusão do ser humano. Freire (1996) quando descreve que não há docência sem discência, remete a um ensino no qual o professor aprende ao ensinar. A reflexão sobre a incompletude do formador pode ser caracterizada como uma potencialidade para o processo formativo das licenciandas nessa constante problematização e reconhecimento de que podem saber mais (Freire, 1977). É essa inconclusão, consciência do inacabamento na docência, que direciona o processo formativo e caracteriza em parte a problematização. Freire (1996) destaca a ideia de que ensinar não é um mecanismo de transferir conhecimento, mas uma possibilidade para que haja a construção dele. Assim, fica explícito que o ensinar e o aprender são processos que dependem de ações docentes e discentes, numa construção mútua de conhecimentos em um constante processo de "re-admirar" a realidade. É nesse processo contínuo que se estabelece uma relação dialógica permanente, como realçou o formador: "Agora penso que estamos em uma etapa da escrita do nosso diário que é refletir sobre como poderíamos revisar as atividades desenvolvidas. Como quem diz: 'se identificamos problemas nas nossas ações podemos refletir sobre como enfrentálos"' (F). O processo de formação exige a construção e a reconstrução permanente do conhecimento. Neste trecho destacado é possível identificar que o formador fomenta a reflexão em revisar as atividades já desenvolvidas. É a partir dessa problematização, crítica e criticando que podemos atuar como sujeitos da transformação (Freire, 1977).

Em suma, a problematização promovida pelo formador no desenvolvimento de uma proposta de abordagem temática em um estágio curricular supervisionado na componente curricular Química no Ensino Médio foi caracterizada por reflexões que remetem a consciência da inconclusão da docência. $O$ formador compartilha reflexões com as licenciandas que podem se relacionar com a necessidade de se apropriarem de novos conhecimentos sobre o Ensino de Química, ao mesmo tempo em que explicita as reflexões sobre a sua própria prática pedagógica não somente no processo de desenvolvimento do projeto de abordagem temática, mas também no planejamento dele. Ao mesmo tempo em que o formador explicita suas reflexões, defende seu ponto de vista e valoriza o incentivo para a reflexão das licenciandas sobre o planejamento e desenvolvimento do projeto.

\section{Considerações finais}

A problematização do formador não se limitou a dado momento do processo formativo. Ela esteve continuamente presente nesse processo e articulada a diferentes dimensões do projeto de abordagem temática para o contexto de estágio supervisionado de Química, tais como o planejamento, o desenvolvimento na escola, as estratégias 
didáticas, a atuação das licenciandas, seus conhecimentos explicitados e a prática do próprio formador. Além disso, a amplitude da problematização em torno dos diferentes aspectos da docência não se restringiu às contribuições propriamente da abordagem temática em harmonia com as ideias de Paulo Freire, pois contemplou questões mais amplas do Ensino de Ciências.

Nesta direção, a análise é sugestiva da necessidade de se investir em pesquisas que considerem o exame de conhecimentos mobilizados da área de Ensino de Ciências da Natureza por docentes no planejamento, no desenvolvimento e na avaliação de projetos de abordagem temática, de acordo com a perspectiva de educação defendida por Paulo Freire. Da análise foi possível apreender a importância de se dialogar com conhecimentos das licenciandas sobre temáticas amplamente estudadas pela pesquisa em Ensino de Ciências, como as atividades experimentais. Por exemplo, é imperativo que os conhecimentos docentes a respeito das atividades experimentais, inseridas em processos educativos planejados de acordo com as ideias de Paulo Freire, estejam coerentes com as ideias desse autor, de maneira que as atividades experimentais expressem uma visão educacional que contradiga aquela que valoriza estudantes como supostos depósitos de conhecimentos - visão criticada por Freire (2005). Subjacente a isso se encontra a necessidade de pesquisadores em Ensino de Ciências também investirem em estudos que colaborem na construção de conhecimentos que possam culminar na sinalização de estratégias didáticas que estejam de acordo com as ideias de Paulo Freire. As reflexões expostas na análise acerca das atividades experimentais indicam que essa temática pode ser uma daquelas a receberem os esforços de pesquisadores para que se possa vislumbrar possíveis modos de sua utilização em sintonia com as ideias educacionais de Paulo Freire. Essas considerações se estendem também há outras estratégias que se utilizam em outras componentes curriculares que não as da área de Ciências da Natureza, mas que igualmente são objeto da pesquisa em Ensino de Ciências, como os trabalhos em pequenos grupos, do mesmo modo citados na análise. No âmbito da pesquisa sobre a atuação de formadores de professores de Química/Ciências da Natureza ainda cabe valorizar a necessidade de estudos relativos à análise de conhecimentos mobilizados da área de Ensino de Ciências da Natureza por esses profissionais ao trabalharem com professores da Educação Básica no planejamento, no desenvolvimento e na avaliação de projetos de abordagem temática fundamentados nas ideias de Paulo Freire. Na pesquisa aqui apresentada não se apresentaram análises mais aprofundadas que contemplassem os conhecimentos da área de Ensino de Ciências, a exemplo daqueles sobre as atividades experimentais e trabalhos em pequenos grupos, mobilizados pelas licenciandas e pelo formador durante todo o processo formativo. Contudo, a partir do próprio diário virtual coletivo e de outros materiais disponíveis, como os planos de aula, pode-se ter como um desdobramento do trabalho a análise constituinte de um processo de comunicação, como aqui caracterizado, desses conhecimentos da área de Ensino de Ciências mobilizados. Entende-se que é indesejável reduzir o olhar apenas a conhecimentos associados a o "como ensinar", como são em parte aqueles associados às atividades experimentais, por 
exemplo. Possíveis conhecimentos mobilizados da área de Ensino de Ciências sobre "o que ensinar" também merecem ser objeto de análise. Seja como for, para além da caracterização metodológica da problematização é igualmente relevante elucidar o conteúdo da problematização. Como destacou Freire (1977) qualquer conteúdo pode ser problematizado.

Ademais, cumpre registrar que a problematização se caracterizou pelo respeito ao conhecimento das licenciandas, bem como pela reflexão concernente ao caráter inacabado da docência, de acordo com o já exposto na análise. Essas características da problematização podem auxiliar a entender os resultados da pesquisa preliminar (Silveira et al., 2020) que investigou conhecimentos explicitados pelas licenciandas acerca dos limites e das potencialidades da abordagem temática realizada em tal estágio. Assim, entende-se que limitações identificadas no próprio conhecimento das licenciandas relativo às suas interpretações sobre limites e potencialidades da abordagem temática podem estar mais associadas às opções metodológicas adotadas pelo formador na condução do projeto de abordagem temática que suprimiu etapas da investigação temática proposta por Freire (2005) do que nas ações do formador, uma vez que foi possível apreender características importantes no processo de problematização desenvolvido por ele. Já se havia suscitado previamente (Silveira et al., 2020) que a utilização de parte das etapas da investigação temática poderia ter influenciado no processo de apropriação das licenciandas da abordagem temática fundamentada nas contribuições teórico-metodológicas de Freire. Isso vai na direção de resultados já apontados na literatura que chamam a atenção para limitações decorrentes da "adaptação" do processo de investigação temática (Neres \& Gehlen, 2018). Em outras palavras, as limitações previamente identificadas em conhecimentos explicitados pelas licenciandas parecem que não estão diretamente relacionadas com a problematização promovida pelo formador. Com isso se reforça, em parte, a potencialidade da dinâmica escolhida com atividades de explicitação de conhecimentos e de apropriação de novos conhecimentos mediadas pela problematização (Gonçalves et al., 2019).

Essas considerações não tratam, por outro lado, de desvalorizar a utilização das etapas levantamento preliminar, redução temática e sala de aula a partir das contribuições de Sousa et al. (2015). Os resultados apontados nesta pesquisa correlata supramencionada indicam também contribuições que essas etapas podem ter quando utilizadas em contextos de estágio supervisionado e vinculadas a outras dinâmicas.

Nesta direção, cumpre registrar que a problematização também se estendeu por meio da pesquisa em parceria entre formador e licenciandas que culminou neste trabalho e que favorece uma educação humanizadora à medida que pode colaborar para a continuidade do desvelamento da realidade e da sua transformação. Ademais, com o exposto neste trabalho sobre a problematização, entende-se que se consegue avançar na sua caracterização em processos de formação de professores que envolvem o estudo da abordagem temática. Uma vez que Magoga e Muenchen (2018) identificaram na prática de pesquisadores em Ensino de Ciências da Natureza, especialistas em abordagem 
temática, a problematização como um dos pressupostos da obra de Paulo Freire que orientam as suas ações formativas, julga-se que é necessário investir em pesquisas que busquem elucidar as características dessa problematização, de modo a favorecer a sua promoção na formação de professores.

$\mathrm{O}$ uso do diário virtual coletivo como ferramenta pedagógica possibilitou ao formador e às licenciandas apreenderem seus conhecimentos em uma constante "readmiração". Depreende-se disso a necessidade de entender o papel da problematização mediada pelo processo de pesquisa em parceria entre o formador e estudantes de cursos de licenciatura na investigação de aspectos da abordagem temática fundamentada em ideias de Paulo Freire promovida em oportunidades formativas na graduação, a exemplo do estágio.

\section{Referências}

Almeida, E. S., \& Gehlen, S. T. (2019). Organização curricular na perspectiva Freire-CTS: propósitos e possibilidades para a educação em ciências. Ensaio: Pesquisa em Educação em Ciências, 21, 1-24. https://doi.org/10.1590/1983-21172019210126

Alves, A. H. B., \& Silva, A. F. G. (2015). Manifestações de obstáculos gnosiológicos para a seleção de conteúdos na implementação de um currículo crítico em ciências naturais. Alexandria: Revista de Educação em Ciência e Tecnologia, 8(1), 181-207. https://doi. org/10.5007/1982-5153.2015v8n1p181

Bomfim, M. G., \& Gehlen, S. T. (2018). Abordagem temática freireana: a superação de obstáculos gnosiológicos na formação de professores. Revista Iberoamericana de Educación, 76(2), 29-50. https://doi.org/10.35362/rie7623091

Bonals, J. (2003). O trabalho em pequenos grupos em sala de aula. Artmed.

Caamaño, A. (2018). Enseñar Química en contexto: un recorrido por los proyectos de Química en contexto desde la década de los 80 hasta la actualidad. Educación Química, 29(1), 21-54. https://doi.org/10.22201/fq.18708404e.2018.1.63686

Centa, F. G., \& Muenchen, C. (2016). O despertar para uma cultura de participação no trabalho com tema gerador. Alexandria: Revista de Educação em Ciência e Tecnologia, 9(1), 263-291. https://doi.org/10.5007/1982-5153.2016v9n1p263

Cruz, G. B. C., \& Magalhães, P. A. (2017). O ensino de didática e a atuação do professor formador na visão de licenciandos de educação artística. Educação e Pesquisa, 43(2), 483-498. https://doi.org/10.1590/S1517-9702201701156893

Delizoicov, D. (1982). Concepção problematizadora para o ensino de ciências na educação formal: relato e análise de uma prática educacional na Guiné-Bissau (Dissertação de Mestrado, Universidade de São Paulo, São Paulo, São Paulo).

Delizoicov, D. (1991). Conhecimento, tensões e transições (Tese de Doutorado, Universidade de São Paulo, São Paulo, São Paulo). 
Delizoicov, D., Angotti, J. A., \& Pernambuco, M. M. (2002). Ensino de Ciências: Fundamentos e Métodos. Cortez.

Fernandes, C. S. (2016). O desenvolvimento profissional dos formadores de professores de Química na interação entre universidade e escola: as potencialidades do programa institucional de bolsa de iniciação à docência (Tese de Doutorado, Universidade Federal de Santa Catarina, Florianópolis, Santa Catarina). Repositório Institucional da UFSC. https://repositorio.ufsc.br/xmlui/handle/123456789/167757

Fernandes, C. S., Marques, C. A., \& Delizoicov, D. (2016). Contextualização na formação inicial de professores de ciências e a perspectiva educacional de Paulo Freire. Ensaio: Pesquisa em Educação em Ciências, 18(2), 9-28. https://doi.org/10.1590/198321172016180201

Ferreira, M. V., Mazocco Paniz, C., \& Muenchen, C. (2016). Os três momentos pedagógicos em consonância com a abordagem temática ou conceitual: uma reflexão a partir das pesquisas com olhar para o ensino de ciências da natureza. Ciência e Natura, 38(1), 513-525.

Francisco, C. A., \& Queiroz, S. L. (2008). A produção do conhecimento sobre Ensino de Química nas Reuniões Anuais da Sociedade Brasileira de Química: uma revisão. Química Nova, 31(8), 2100-2110.

Francisco Júnior, W., Ferreira, L. H., \& Hartwig, D. R (2008). Experimentação problematizadora: fundamentos teóricos e práticos para a aplicação em salas de aula de ciências. Química Nova na Escola, (30), 34-41.

Freire, P. (1977). Extensão ou comunicação?. Paz e Terra.

Freire, P. (1981). Criando métodos de pesquisa alternativa: aprendendo a fazê-la melhor através da ação. In C. R. Brandão (Org), Pesquisa participante (4ª ed., pp. 34-41). Editora Brasiliense.

Freire, P. (1996). Pedagogia da Autonomia: saberes necessários à prática docente (34ㄹ ed.). Paz e Terra.

Freire, P. (2005). Pedagogia do Oprimido (40ª ed.). Paz e Terra.

Freire, P. (2008). A importância do ato de ler: em três artigos que se complementam (49a ed.). Cortez.

Galiazzi, M. C. (2003). Educar pela pesquisa: ambiente de formação de professores de ciências. Unijuí.

Gonçalves, F. P. (2020). Análise textual discursiva como constituinte de um processo de comunicação. Revista Pesquisa Qualitativa, 8(19), 722-738. https://doi.org/10.33361/ RPQ.2020.v.8.n.19.370 
Gonçalves, F. P., Biagini, B., \& Guaita, R. I. (2019). As transformações e as permanências de conhecimentos sobre atividades experimentais em um contexto de formação inicial de professores de Química. Investigações em Ensino de Ciências, 24(3), 101-120.

Gonçalves, F. P., Fernandes, C. S., Lindemann, R. H., \& Galiazzi, M. C. (2008). O diário de aula coletivo no estágio da Licenciatura em Química: dilemas e seus enfrentamentos. Química Nova na Escola, (30), 42-48.

Gonçalves, F. P., \& Marques, C. A. (2013). Problematización de las actividades experimentales en la formación y la práctica docente de los formadores de profesores de Química. Enseñanza de las Ciencias, 31(3), 67-86.

Halmenschlager, K. R., \& Delizoicov, D. (2017). Abordagem temática no ensino de ciências: caracterização de propostas destinadas ao Ensino Médio. Alexandria: Revista de Educação em Ciência e Tecnologia, 10(2), 305-330. https://doi.org/10.5007/1982$5153.2017 \mathrm{v} 10 \mathrm{n} 2 \mathrm{p} 305$

Halmenschlager, K. R., Strieder, R. B., Watanabe, G., \& Silva, L. F. (24-27 de novembro, 2015). Abordagem Temática na formação inicial de professores de Física e suas implicações na prática docente. Anais do X Encontro Nacional de Pesquisa em Educação em Ciências. http://www.abrapecnet.org.br/enpec/X-enpec/anais2015/resumos/R0858-1.PDF

Hunsche, S. (2015). Docência no ensino superior: abordagem temática nas licenciaturas da área de Ciências da Natureza (Tese de Doutorado, Universidade Federal de Santa Catarina, Florianópolis, Santa Catarina). Repositório Institucional da UFSC. https:// repositorio.ufsc.br/xmlui/handle/123456789/169473

Jesus, A. M. P., \& Razera, J. C. C. (2020). Paulo Freire em artigos sobre formação de professores na área brasileira de educação em ciências [1996-2018]: uma análise de citações. Investigações em Ensino de Ciências, 25(3), 361-378. http://dx.doi. org/10.22600/1518-8795.ienci2020v25n3p361

Magoga, T., \& Muenchen, C. (2018). A abordagem temática na educação em ciências: a caracterização de um estilo de pensamento. Alexandria: Revista de Educação em Ciência e Tecnologia, 11(2), 131-157. https://doi.org/10.5007/1982-5153.2018v11n2p131

Magoga, T., \& Muenchen, C. (2020). A Abordagem Temática caracterizada por pesquisadores da área de Ensino de Ciências. Revista Brasileira de Pesquisa em Educação em Ciências, 20, 315-343. https://doi.org/10.28976/1984-2686rbpec2020u315343

Maldaner, O. A. (2000). A formação inicial e continuada de professores de Química: professores/pesquisadores. Unijuí.

Milli, J. C. L., Solino, A. P., \& Gehlen, S. T. (2018). A Análise Textual Discursiva na Investigação do Tema Gerador: por onde e como começar?. Investigações em Ensino de Ciências, 23(1), 200-229. http://dx.doi.org/10.22600/1518-8795.ienci2018v23n1p200 
Minayo, M. C. S. (2017). Amostragem e saturação em pesquisa qualitativa: consensos controvérsias. Revista Pesquisa Qualitativa, 5(7), 1-12. https://editora.sepq.org.br/ index.php/rpq/article/view/82

Moraes, R. (2003). Uma tempestade de luz: a compreensão possibilitada pela análise textual discursiva. Ciência \& Educação, 9(2), 191-211. https://doi.org/10.1590/S151673132003000200004

Moraes, R., \& Galiazzi, M. C. (2007). Análise Textual Discursiva. Unijuí.

Moro, L., Mortimer, E. F., Quadros, A. L., Coutinho, F. A., Silva, P. S., Pereira, R. R., \& Santos, V. C. (2015). Influência de um terceiro modo semiótico na gesticulação de uma professora de Química. Revista Brasileira de Pesquisa em Educação em Ciências, 15(1), 9-32. https://periodicos.ufmg.br/index.php/rbpec/article/view/4300

Neres, C. A., \& Gehlen, S. T. (2018). Investigação Temática na formação de professores: indicativos da pesquisa em Educação em Ciências. Revista Brasileira de Pesquisa em Educação em Ciências, 18(1), 239-267. https://doi.org/10.28976/19842686rbpec2018181239

Oliveira, L., \& Mortimer, E. F. (2020). Os percursos de transformação da ação mediada por recursos educacionais: o ponto de vista de uma professora de Química orgânica de ensino superior. Ensaio: Pesquisa em Educação em Ciências, 22, 1-24. https://doi. org/10.1590/1983-21172020210134

Razera, J. C. C., Matos, C. M. S., \& Bastos, F. (2019). Um perfil métrico das pesquisas que destacam a formação de professores na área brasileira de educação em ciências. Investigações em Ensino de Ciências, 24(1), 200-222. http://dx.doi.org/10.22600/15188795.ienci2019v24n1p2000

Santos, F. M. T., \& Greca, I. M. (2013). Metodologias de pesquisa no ensino de ciências na América Latina: como pesquisamos na década de 2000. Ciência \& Educação, 19(1), 15-33. https://doi.org/10.1590/S1516-73132013000100003

Santos, W. L. P. (2009). Scientific literacy: a freirean perspective as a radical view of humanistic science education. Science Education, 93(2), 361-382. https://doi. org/10.1002/sce.20301

Silva, O. B., \& Queiroz, S. L. (2016). Mapeamento da pesquisa no campo da formação de professores de Química no Brasil. Investigações em Ensino de Ciências, 21(1), 62-93. http://dx.doi.org/10.22600/1518-8795.ienci2016v21n1p62

Silva, R. A., Silva, F. N., \& Suart, R. C. (2020). Ações e reflexões vivenciadas por uma professora em formação inicial por meio de elaboração de planos e regência de aulas: contribuições do processo de reflexão orientada. Revista Brasileira de Pesquisa em Educação em Ciências, 20(u), 1169-1196. https://doi.org/10.28976/19842686rbpec2020u11691196 
Silveira, R. A., Piaia, L., \& Gonçalves, F. P. (2020). A problematização da abordagem temática na formação inicial de professores de Química. Química Nova, 43(10), 15291539.

Solino, A. P., \& Gehlen, S. T. (2015). O papel da problematização freireana em aulas de ciências/física: articulações entre a abordagem temática freireana e o ensino de ciências por investigação. Ciência \& Educação, 21(4), 911-930. https://doi.org/10.1590/1516731320150040008

Sousa, P. S. de, Santos, L. H. da S., Reis, Y. A. dos, \& Gehlen, S. T. (26-30 de janeiro, 2015). Abordagem temática freireana no ensino de ciências/física: uma experiência no estágio supervisionado em física. In XXI Simpósio Nacional de Ensino de Física. Uberlândia, Brasil.

Sousa, P. S. de, Bastos, A. P. S., Figueiredo, P. S. de, \& Gehlen, S. T. (2016). Tema Gerador e a Relação Universidade-Escola: Percepções de Professoras de Ciências de uma Escola Pública em Ilhéus-BA. Alexandria: Revista de Educação em Ciência e Tecnologia, 9(1), 3-29. https://doi.org/10.5007/1982-5153.2016v9n1p3

Spelta, L. M. P. B., Nunes, F. P. B., Silva, J. R. S., Ursi, S., \& Prestes, M. E. B. (2012). A pesquisa-ação na prática docente na disciplina Introdução ao Ensino de Biologia do curso de Ciências Biológicas do Instituto de Biociências da Universidade de São Paulo. Revista Brasileira de Pesquisa em Educação em Ciências, 12(2), 71-92. https://periodicos. ufmg.br/index.php/rbpec/article/view/4231

Torres, J. R., Gehlen, S. T., Muenchen, C., Gonçalves, F. P., Lindemann, R. H., \& Gonçalves, F. J. F. (2008). Resignificação curricular: contribuições da investigação temática e da análise textual discursiva. Revista Brasileira de Pesquisa em Educação em Ciências, 8(2), 1-13. https://periodicos.ufmg.br/index.php/rbpec/article/view/4021

Zabalza, M. A. (2004). Diários de aula: um instrumento de pesquisa e desenvolvimento profissional. Artmed. 
Fábio Peres Gonçalves

Universidade Federal de Santa Catarina

Florianópolis, Santa Catarina, Brasil fabio.pg@ufsc.br

${ }^{10}$ Renata Aragão da Silveira

Universidade Federal de Santa Catarina

Florianópolis, Santa Catarina, Brasil reeharagao@hotmail.com

${ }^{\circ}$ Lya Piaia

Universidade Federal de Santa Catarina

Florianópolis, Santa Catarina, Brasil

lyapiaia@hotmail.com

Editora Responsável

Stefannie Ibraim

Manifestação de Atenção às Boas Práticas Científicas e de Isenção de Interesse

Os autores declaram ter cuidado de aspectos éticos ao longo do desenvolvimento da pesquisa e não ter qualquer interesse concorrente ou relações pessoais que possam ter influenciado o trabalho relatado no texto. 